\title{
PENGEMBANGAN SISTEM INFORMASI PELAYANAN SURAT MENYURAT (SIRA) BERBASIS WEBSITE DENGAN MENGGUNAKAN FRAMEWORK CODEIGNITER
}

\author{
Ahmad Syaebani ${ }^{1)}$, Dita Via Tyasmala ${ }^{2)}$, Rahma Maulani ${ }^{3)}$, Erina Dwi Utami ${ }^{4)}$, \\ Sri Ngudi Wahyuni ${ }^{5)}$ \\ 1) Manajemen Informatika Universitas AMIKOM Yogyakarta \\ email : ahmad.syaebani@students.amikom.ac.id ${ }^{1)}$,dita.tyasmala@students.amikom.ac.id ${ }^{2)}$, \\ rahma.0313@students.amikom.ac.id ${ }^{3)}$,erina.28@students.amikom.ac.id ${ }^{4)}$, yuni@amikom.ac.id ${ }^{5}$.
}

\begin{abstract}
Abstraksi
Layanan surat menyurat merupakan hal penting dalam proses penyelesaian administrasi di masyarakat. Kelurahan Mendawai merupakan salah satu kelurahan yang terletak di Jln. Dewan Amir Husin Hamzah Nomor: 22, Kelurahan Mendawai, Kecamatan Arut Selatan, Kabupaten Kotawaringin Barat, Provinsi Kalimantan Tengah dan saat ini membutuhkan sistem untuk mempermudah layanan surat menyurat guna memberikan layanan prima kepada masyarakat. Selama ini, layanan administasi dan surat menyurat dilakukan dengan sistem konvensional, yaitu dengan langsung datang kelokasi. Warga harus menemui ketua RT meminta persetujuan permohonan surat, kemudian datang ke kantor kelurahan untuk mengajukan permohonan surat yang dibutuhkan tersebut. Cara tersebut dirasa kurang efektif dan kurang efisien karena membutuhkan waktu yang cukup lama untuk melakukan pemrosesan surat. Pada penelitian ini akan diberikan solusi bagaimana pengembangan sistem informasi surat menyurat berbasis website. Pada sistem informasi ini melayani 14 jenis surat yang dapat diajukan dan 7 jenis surat download template. Sistem informasi ini hanya dapat diakses oleh warga, ketua RT, kepala desa maupun admin pengelola website yang datanya telah tercatat dalam database. Sistem ini dibuat menggunakan Bahasa Pemrograman PHP dengan Framework CodeIgniter, dan MySQL sebagai Database Management System. Dalam melakukan pengujian sistem ini, penulis menggunakan metode white box testing dan System Usability Scale (SUS). Hasil yang diperoleh dari penelitian ini adalah Sistem Informasi Surat Menyurat (SIRA) berbasis Website yang akan mempermudah pelayanan surat menyurat di Kelurahan Mendawai.
\end{abstract}

Kata Kunci :

Sistem Informasi, Layanan Surat Menyurat, Website, CodeIgniter, Bootstrap

\begin{abstract}
The services administration is an important thing in administrative sociaty problem soulving. Mendawai is one of the sub-districts located on Jln. Dewan Amir Husain Hamzah Number: 22, Mendawai Village, Arut Selatan, Kotawaringin Barat, Kalimantan Tengah and to day need a system for make it easier to exelent servise for society administration. In Mendawai Village, especially in filing letters, are still done manually. The residents had to meet with the RT head to ask for approval of the letter application, then came to the village office to apply for the required letter. This method is deemed less effective and less efficient because it requires a long time to process the letter. Based on these problems, the authors provide a solution in the form of a website-based correspondence information system. This information system serves 14 types of letters that can be submitted and 7 types of letter template downloads. This information system can only be accessed by residents, RT heads, village heads and website administrators whose data has been recorded in the database. This system is built using the PHP programming language with CodeIgniter Framework, and MySQL as the Database Management System. In testing this system, the authors use the White Box Testing method and the System Usability Scale (SUS). The results obtained from this implementation is a Website-Based Information System for Correspondence (SIRA) which will facilitate correspondence services at the Mendawai Village.
\end{abstract}

\section{Keywords :}

Correspondence Service Information System, Website, CodeIgniter, Bootstrap

\section{Pendahuluan}

Kelurahan Mendawai adalah sebuah kelurahan atau pembagian wilayah administratif di Indonesia dibawah Kecamatan Arut Selatan yang tepatnya terletak di Jln. Dewan Amir Husin Hamzah Nomor: 22, Kelurahan Mendawai, Kecamatan Arut
Selatan, Kabupaten Kotawaringin Barat, Provinsi Kalimantan Tengah. Kelurahan ini memiliki 30 RT dan warga yang berjumlah 11.000 orang. Media informasi dari Kelurahan Mendawai ini berbentuk media sosial yaitu Facebook di laman Kelurahan Mendawai. Untuk menyampaikan informasi 
memanglah lebih familiar menggunakan Facebook, hampir semua orang juga saat ini memiliki akun di Facebook.

Karena Facebook hanya dapat digunakan untuk berbagi informasi atau pengumuman mengenai suatu hal maka untuk manajemen surat menyurat masih menggunakan cara manual yaitu warga datang kepada ketua RT setempat untuk persetujuan permohonan surat, kemudian baru diajukan ke kelurahan. Jika sudah dikonfirmasi dan ditandatangani di kelurahan barulah surat tersebut jadi dan dapat diambil oleh warga di kelurahan. Warga harus bolak-balik untuk mendapatkan surat. Harus datang ke ketua RT terlebih dahulu kemudian datang ke kelurahan, di kelurahan juga belum tentu langsung jadi surat yang diminta tersebut. Harus kembali ke rumah, lalu menunggu hari surat jadi. Ketika mengajukan permohonan surat atau mengambil surat yang sudah jadi di kelurahan warga harus melakukan antri, yang mana dapat membuat kerumunan.

Di situasi Pandemi Covid-19 ini, telah dikeluarkan kebijakan untuk mematuhi protokol kesehatan serta mengurangi kerumunan. Walaupun saat datang ke kelurahan menggunakan protokol kesehatan, tetapi jika dapat mengurangi kontak fisik secara langsung dan mengurangi antrian dari sisi pelayanan surat menyurat akan lebih baik. Selain itu, dari pihak kelurahan saat ini melakukan pengelolaan surat yang diterbitkan, surat masuk kedinasan, dan surat keluar kedinasan masih manual menggunakan buku yang dimana itu beresiko terjadi kerusakan. Jika pengelolaan dilakukan dengan digital maka akan meningkatkan kinerja karyawan menjadi lebih efektif dan efisien serta mengurangi penggunaan kertas.

Maka dari itu, Kelurahan Mendawai membutuhkan sistem informasi berbasis website yang dapat mempermudah pelayanan surat menyurat secara online. Aplikasi berbasis website dapat menjadi solusi untuk dijadikan sistem informasi pelayanan surat menyurat secara online. Aplikasi berbasis website dirancang agar warga yang ingin mengajukan permohonan sebuah surat dapat melakukannya secara online dan dapat dilakukan dari mana saja terutama dari rumah.

Ketua RT yang harus menyetujuinya dan konfirmasi juga dapat melakukannya secara online. Dengan begitu dapat diteruskan kepada admin kelurahan yang dapat memperbarui dan monitoring mengenai permohonan dan pelayanan surat menyurat. Setelah surat disetujui, maka warga dapat mengunduh surat secara mandiri atau datang ke kelurahan untuk mencetak surat melalui admin.

Sistem ini dikembangkan untuk mengajukan permohonan 14 jenis surat dan 7 surat yang bersifat download template. Adapun 14 jenis surat tersebut meliputi surat keterangan usaha, surat keterangan domisili, surat keterangan belum memiliki rumah, surat keterangan beda nama, surat keterangan izin keramaian, surat keterangan belum pernah menikah, surat keterangan tidak mampu, surat keterangan janda, surat keterangan kematian, surat keterangan kelahiran, surat pengantar KTP, surat pengantar KK, surat keterangan penghasilan, dan surat keterangan pindah. Sedangkan 7 jenis surat yang bersifat download template meliputi surat keterangan kepemilikan tanah, surat keterangan penyerahan waris, surat keterangan ahli waris, surat pengantar nikah, surat keterangan penyerahan tanah, surat rekomendasi izin mendirikan bangunan, dan surat rekomendasi usaha mikro kecil. Kemudian untuk keperluan evaluasi, warga dapat menyampaikan keluh kesah mengenai pelayanan atau lainnya melalui fitur pesan pengaduan. Selain memudahkan warga, aplikasi ini juga memudahkan admin untuk melakukan pengelolaan data warga, data ketua RT, data kepala desa, data surat yang diterbitkan, data surat masuk kedinasan, data surat keluar kedinasan, dan data pengaduan secara sistematis. Sehingga dapat membantu proses pembuatan laporan yang dibutuhkan untuk pejabat yang berwenang.

Aplikasi berbasis website cukup mudah digunakan, karena pengguna tidak harus mengunduh dan install untuk mengaksesnya sehingga lebih menghemat ruang penyimpanan pada perangkat atau device. Informasi mengenai pengajuan dan pelayanan surat menyurat dapat diakses secara cepat jika sistem bekerja secara online. Menggunakan sebuah website responsif yang dapat diakses oleh semua perangkat atau device memiliki kemampuan untuk mendukung pelayanan surat menyurat dimanapun. Untuk mempermudah pegembangan sistem ini, maka pengembangannya menggunakan Framework PHP yaitu CodeIgniter dan Framework CSS dan JavaScript yaitu Bootstrap. Adapun tujuan yang ingin dicapai dalam penelitian ini adalah:

a. Mengembangkan sistem informasi untuk memudahkan pelayanan surat menyurat secara online di Kelurahan Mendawai.

b. Mengembangkan sistem informasi untuk memudahkan pegawai atau admin untuk melakukan pengelolaan data warga, data ketua RT, data kepala desa, data surat yang diterbitkan, data surat masuk kedinasan, dan data surat keluar kedinasan secara sistematis serta mempermudah pembuatan laporan.

c. Mengembangkan website responsif sebagai media dan sistem informasi pelayanan surat menyurat dengan menggunakan Framework PHP yaitu CodeIgniter dan Framework CSS dan JavaScript yaitu Bootstrap.

Berdasarkan uraian latar belakang masalah di atas, dapat dirumuskan sebuah permasalahan yaitu Bagaimana mengembangkan sistem informasi pelayanan surat menyurat berbasis website secara online untuk mempermudah pelayanan surat menyurat di Kelurahan Mendawai. 


\section{Tinjauan Pustaka}

[1] Pada penelitian yang berjudul Sistem Informasi Surat Pelayanan Masyarakat Desa Monggol, Kec. Saptosari, Kab. Gunungkidul, Yogyakarta menyatakan bahwa sistem yang dibangun merupakan sistem berbasis desktop yang hanya dapat diakses oleh admin. Sistem tersebut digunakan untuk pencatatan atau pengarsipan permohonan surat yang telah dilakukan oleh warga karena sistem tersebut belum bisa diakses menggunakan internet.

[2] Pada penelitian yang berjudul Sistem Informasi Administrasi Surat Menyurat Desa Selopamioro Berbasis Web menyatakan bahwa sistem yang dibangun dapat mengakomodasi 4 jenis surat yaitu Surat Pengantar KTP, Surat Izin Keramaian, Surat Keterangan Kematian, dan Surat Dispensasi Menikah. Sistem yang dibangun memiliki fungsi untuk pencatatan pengajuan surat di kelurahan, belum mengakomodasi pengajuan dari masyarakat.

Natalia (2019) pada penelitiannya menyatakan bahwa sistem yang dibangun untuk layanan surat berbasis web dapat memudahkan masyarakat dalam memberikan layanan permohonan surat yang diajukan warga melalui sistem. Namun dalam proses pengajuan suratnya, warga masih harus menemui RT/RW/Dukuh untuk meminta surat pengantar sebelum mengajukan melalui sistem dengan cara mengupload surat pengantar yang telah didapat sebelumnya .

[4] Pada penelitian menyatakan bahwa menyatakan bahwa sistem pelayanan surat menyurat berbasis web dapat dengan mudah diakses masyarakat dari mana saja dengan internet. Melalui sistem ini masyarakat dapat mengajukan permohonan surat yang kemudian akan disetujui oleh Ketua RT. Setelah melalui persetujuan RT permohonan surat tersebut akan melalui proses persetujuan admin yang dilakukan di halaman web admin. Setelah permohonan surat selesai diproses, surat tersebut bisa dicetak oleh admin dan diberikan kepada warga yang mengajukan. Sistem ini dapat melayani 9 jenis permohonan surat. Selain itu dalam proses pembuatan surat, tanggal pembuatan surat masih diinputkan secara manual sesuai tanggal surat tersebut dibuat.

[5] Pada penelitian yang berjudul Sistem Informasi Pelayanan Surat-Menyurat Berbasis Web Di Desa Palang Kecamatan Palang Kabupaten Tuban menyatakan bahwa sistem yang dibangun merupakan sistem pelayanan surat berbasis web yang dapat dengan mudah diakses oleh warga dari mana saja selama terdapat jaringan internet. Pengajuan permohonan surat dalam sistem ini dilakukan oleh warga yang kemudian langsung diperiksa dan diproses oleh staf kelurahan. Setelah pemrosesan surat selesai, staf kelurahan akan mengirim informasi pengambilan surat kepada pemohon. Sistem ini dapat melayani 5 jenis permohonan surat seperti surat keterangan pindah, surat keterangan domisili, surat kelahiran, surat kematian dan surat keterangan usaha.
Selain menangani permohonan surat, sistem ini juga dapat membuat laporan kependudukan .

Berdasarkan beberapa uraian diatas maka tujuan penelitian ini adalah melakukan pengembangan Sistem Informasi Pelayanan Surat Menyurat Kelurahan Mendawai ini memudahkan warga untuk melakukan pengajuan surat secara online tanpa harus menemui ketua RT untuk menyetujui permohonan surat, sehingga baru bisa melakukan pengajuan surat di Kelurahan Mendawai. Warga memiliki akun sendiri untuk melakukan pengajuan pembuatan 14 jenis surat serta 7 jenis surat yang bersifat unduh template. Selain itu, warga dapat mengetahui proses dari pelayanan surat mulai dari pengajuan hingga surat tersebut sudah siap dicetak dan dapat digunakan sesuai peruntukannya. Untuk mencetak surat, warga memiliki 2 pilihan yaitu dapat mencetak surat secara mandiri dengan akunnya atau mencetak surat di kelurahan melalui akun admin. Dalam hal ini kepala desa memiliki akses untuk monitoring proses pelayanan surat menyurat.

\section{Bootstrap}

Bootstrap adalah Framework CSS untuk membuat tampilan web. Bootstrap menyediakan class dan komponen yang sudah siap dipakai .

\section{CI (CodeIgniter)}

CodeIgniter adalah kerangka kerja pengembangan aplikasi PHP berdasarkan arsitektur yang terstruktur. CodeIgniter memiliki tujuan untuk memberikan alat bantu yang dibutuhkan seperti helpers and libraries untuk mengimplementasi tugas yang biasa dilakukan. Dengan demikian, pengembangan proyek menjadi lebih mudah dan cepat. Dan pengembang tidak perlu menulis lagi dari awal. CodeIgniter adalah sebuah web application framework yang bersifat open source digunakan untuk membangun aplikasi PHP dinamis. Tujuan utama pengembangan CodeIgniter adalah untuk membantu developer untuk mengerjakan aplikasi lebih cepat daripada menulis semua kode dari awal. CodeIgniter menyediakan berbagai macam library yang dapat mempermudah dalam pengembangan.

\section{MYSQL (My Structured Query Language)}

MySQL (My Structured Query Language) adalah salah satu jenis database server yang sangat terkenal dan banyak digunakan untuk membangun aplikasi web yang menggunakan database sebagai sumber dan pengelolaan datanya. MySQL bersifat open source dan menggunakan SQL (Structured Query Language). MySQL merupakan database yang pertama kali didukung oleh bahasa pemrograman script untuk internet (PHP dan Perl). MySQL sering digunakan untuk membangun aplikasi berbasis web dengan bahasa pemrograman script PHP. MySQL termasuk RDBMS (Relational Database Management System). Pada MySQL, sebuah database mengandung satu atau beberapa tabel dimana sebuah tabel terdiri atas sejumlah kolom dan 
baris, setiap kolom berisi sekumpulan data yang memiliki tipe yang sejenis dan baris merupakan sekumpulan data yang saling berkaitan dan membentuk informasi.

\section{Metode Penelitian}

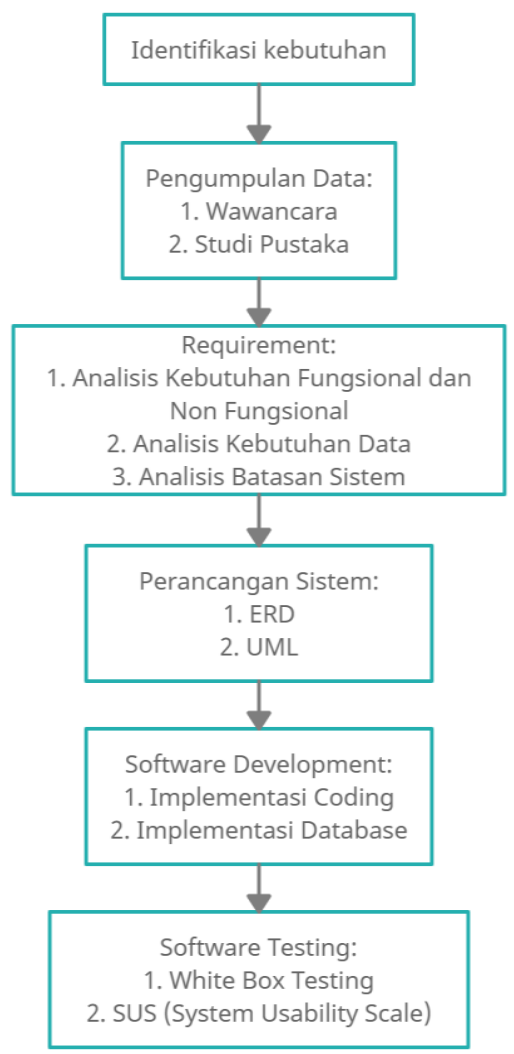

Gambar 1. Alur penelitian

Adapun tahapan penelitian yang dilakukan adalah sebagai berikut:

Tahap pertama adalah identifikasi kebutuhan. Pada tahap ini proses identifikasi kebutuhan merupakan tahapan peneliti untuk mengidentifikasi masalah yang ada pada objek penelitian. Dalam tahap ini berisi mengenai perumusan masalah dan tujuan penelitian.

Tahap kedua yaitu pengumpulan data. Untuk mendapatkan data yang dibutuhkan peneliti menggunakan 2 metode yaitu wawancara dengan pejabat kelurahan secara langsung melalui pertemuan tatap muka dan secara online melalui platform Google Meet dan melakukan studi pustaka. Tahap ketiga yaitu requirement. Pada tahap ini peneliti melakukan analisis kebutuhan fungsional dan non fungsional, analisis kebutuhan data, dan analisis batasan sistem.

Tahap keempat yaitu perancangan sistem. Untuk melakukan perancangan terhadap pengembangan sistem ini peneliti menggunakan Entity Relationship Diagram (ERD) dan Unified Modelling Language (UML).

Tahap kelima yaitu software development. Pada tahap ini merupakan proses dimana sistem dibuat.
Pada tahap ini peneliti melakukan implementasi coding dan implementasi database.

Tahap keenam yaitu software testing. Setelah pembuatan sistem selesai maka selanjutnya dilakukan testing atau uji coba. Untuk melakukan testing ini peneliti menggunakan 2 metode yaitu metode white box testing untuk menguji fungsional software apakah sudah sesuai atau belum dan metode SUS (System Usability Scale) untuk menguji apakah software ini mudah untuk digunakan.

\section{Hasil dan Pembahasan}

Sistem informasi ini berfungsi sebagai media pelayanan surat menyurat yang terintegrasi dengan database sehingga lebih efektif dan efisien. Sistem informasi ini juga dapat melakukan pencatatan suratsurat kedinasan, selain itu juga bisa melakukan cetak laporan data surat-menyurat.

Adapun tahap dalam pengembangan sistem ini sebagai berikut:

\section{Perancangan}

a. Perancangan ERD (Entity Relationship Diagram)

ERD atau Entity Relationship Diagram adalah suatu bentuk diagram yang menjelaskan hubungan antar objek-objek data yang mempunyai hubungan antar relasi. ERD digunakan untuk menyusun struktur data dan hubungan antar data, dan untuk menggambarkannya digunakan notasi, simbol, bagan, dan lainnya.

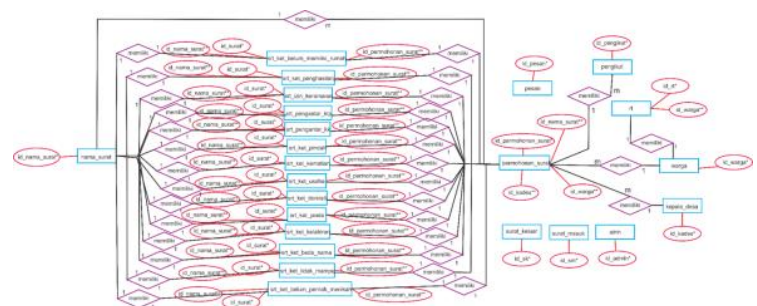

Gambar 2. Entity Relationship Diagram (ERD)

b. Perancangan UML (Unified Modelling Language)

UML adalah salah satu standar bahasa yang banyak digunakan di dunia industri untuk mendefinisikan requirement, membuat analisis dan desain, serta menggambarkan arsitektur dalam pemrograman berorientasi objek.

1) Use Case Diagram dan Deskripsi

a) Aktor

1.Admin.

2. Kepala desa.

3. Ketua RT.

4. Warga. 


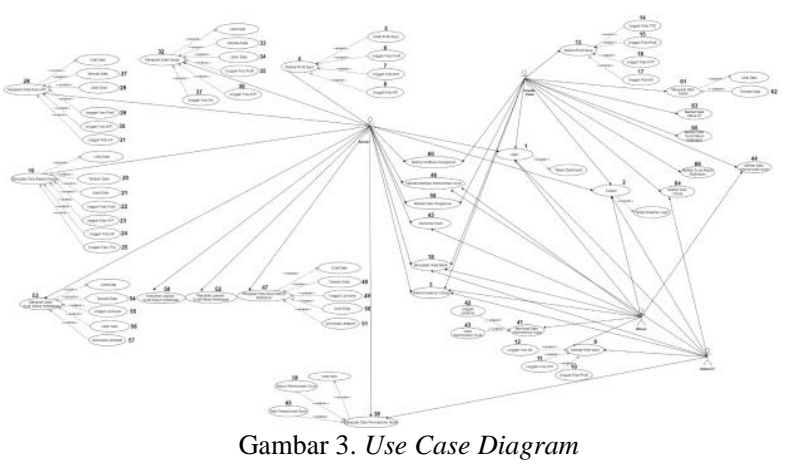

Pada gambar 3 telah digambarkan interaksi yang terjadi antara satu atau lebih aktor dengan sistem yang akan dibuat.

Tabel 1. Deskripsi Use Case Membuat Permohonan Surat

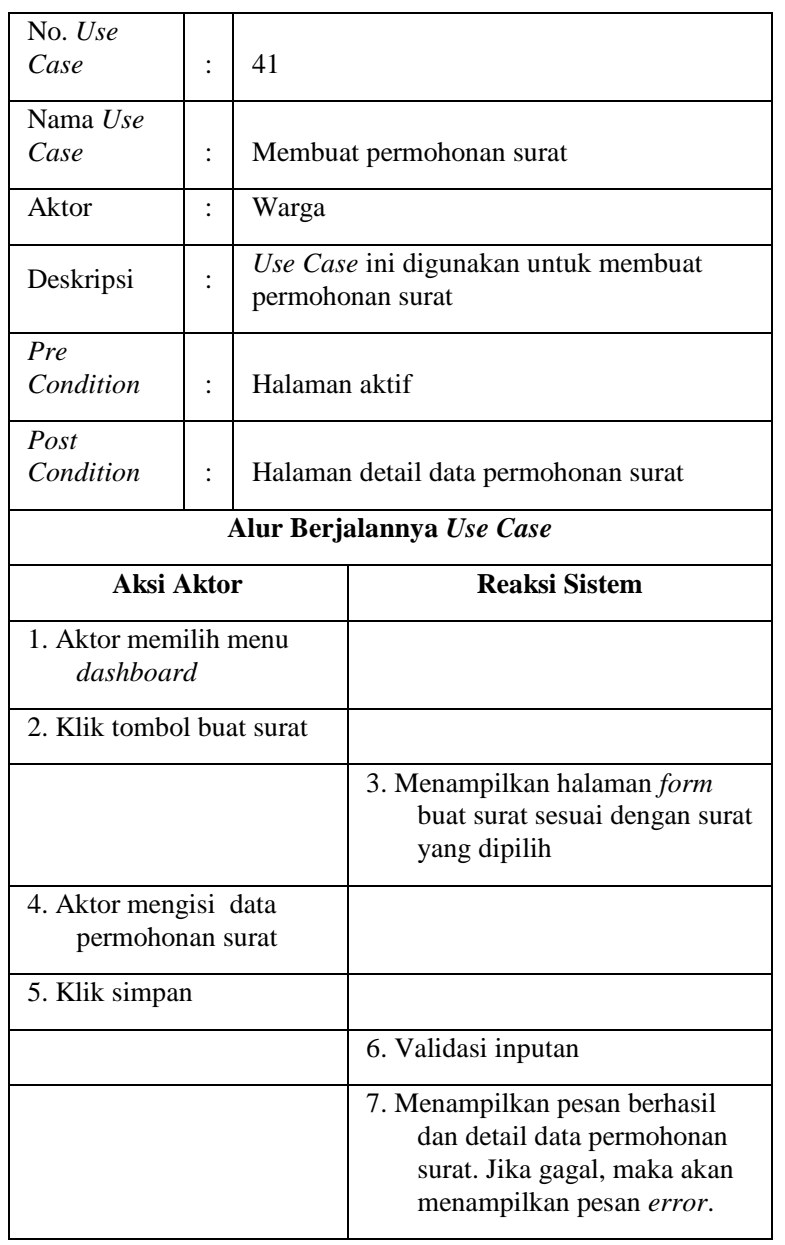

Tabel 1 menjelaskan tentang prosedur pengajuan permohonan surat oleh warga.

\section{2) Activity Diagram}

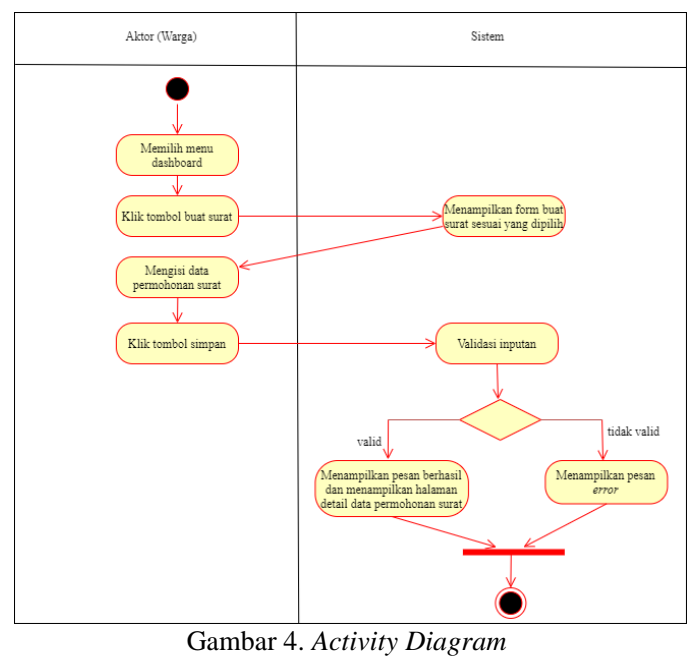

Gambar 3 menggambarkan urutan proses yang terjadi ketika warga mengajukan permohonan surat

3) Class Diagram

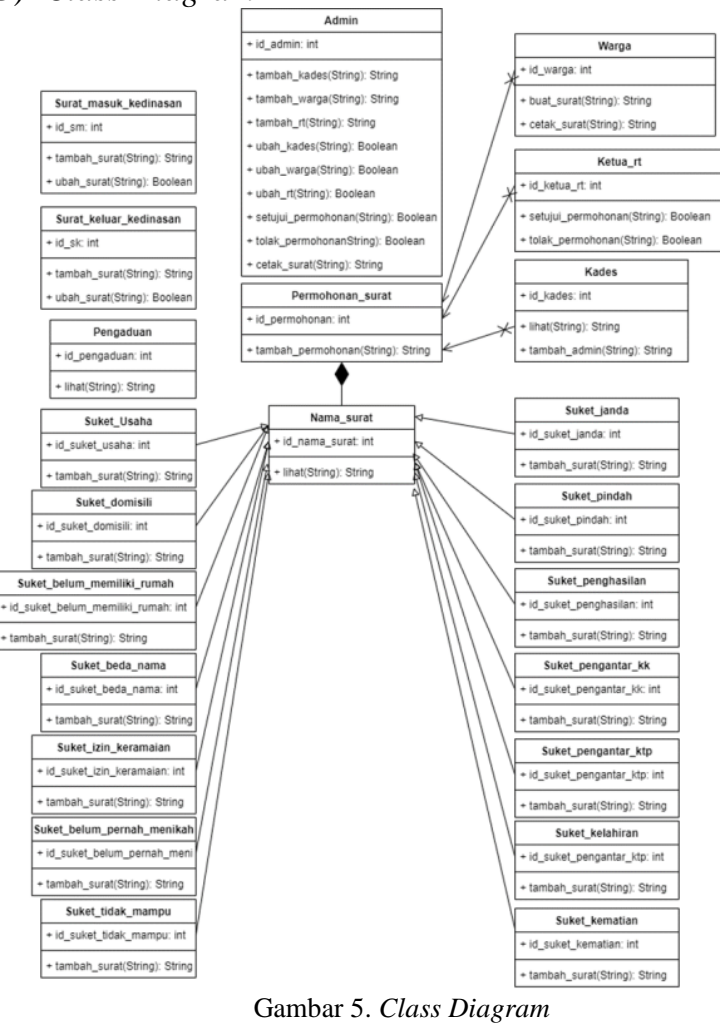

Gambar 5 memvisualisasikan struktur kelas yang ada pada sistem atau program. 


\section{4) Sequence Diagram}

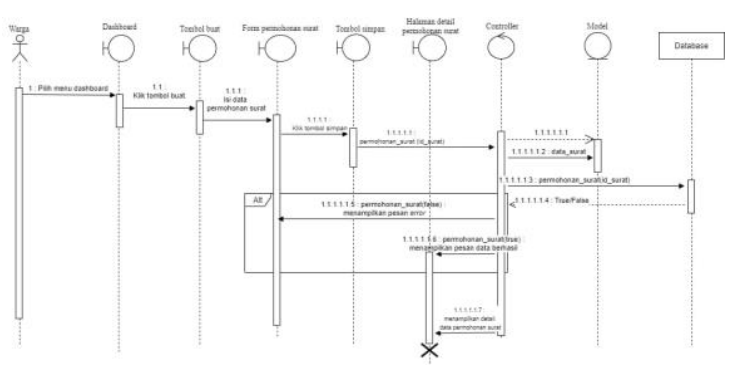

Gambar 6. Entity Relationship Diagram

Gambar 6 menggambarkan perilaku pada skenario pengajuan permohonan surat, dan mendeskripsikan bagaimana interaksi antara entitas dan sistem, termasuk pesan yang digunakan saat interaksi.

\section{Implementasi}

a. Halaman Landingpage

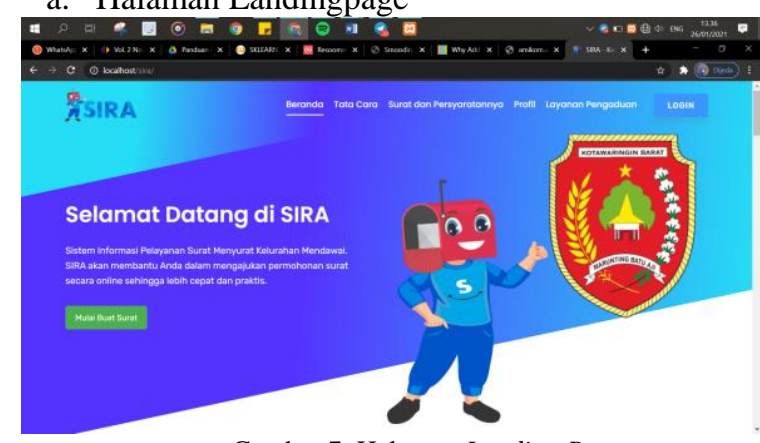

Gambar 7. Halaman Landing Page

Gambar 7 merupakan halaman landing page. Landing Page adalah halaman awal dari SIRA, dihalaman ini disampaikan beberapa informasi mengenai tata cara proses pengajuan surat, informasi profil kelurahan, serta terdapat layanan pengaduan yang dapat digunakan oleh warga untuk melaporkan suatu masalah ke kelurahan.

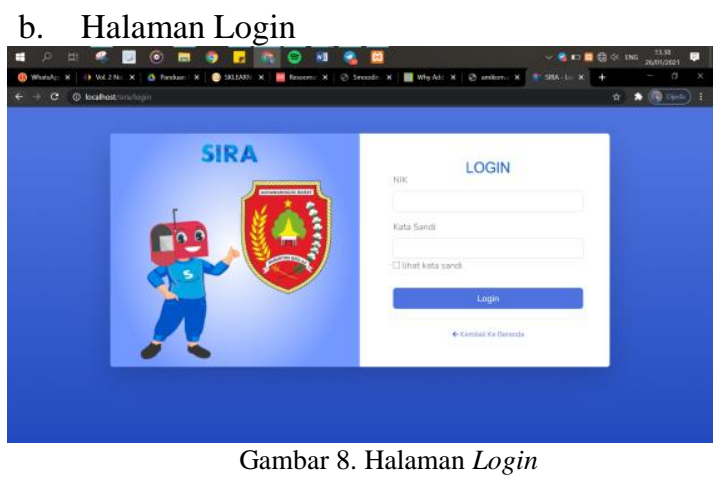

Gambar 8 merupakan tampilan halaman login. Untuk dapat mengakses layanan SIRA pengguna harus melakukan login terlebuh dahulu dengan menginputkan NIK dan Kata Sandi yang sudah terdaftar di dalam database. c. Halaman Form Pengajuan Suart Keterangan Usaha

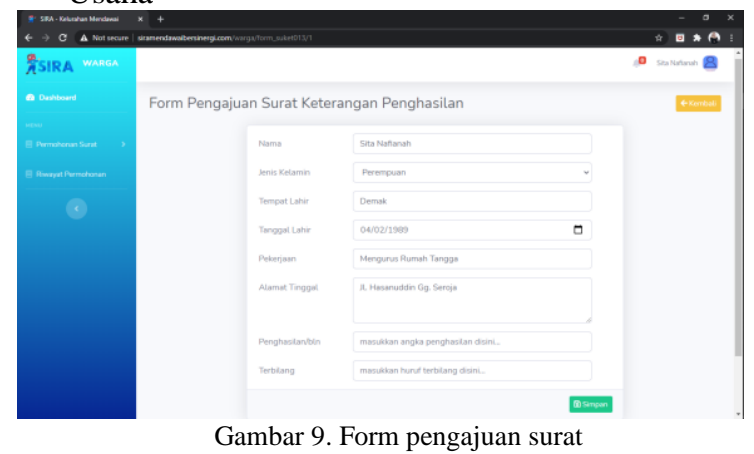

Gambar 9 merupakan salah satu form pengajuan surat. Form pengajuan Surat Keterangan Usaha berfungsi untuk menampung data-data user (warga) yang mengajukan surat, yang mana data-data tersebut nantinya akan diambil dan ditampilkan pada surat keterangan usaha yang sudah di setujui oleh kelurahan.

\section{Pengujian Sistem}

Pengujian Sistem merupakan sebuah proses terhadap aplikasi untuk menemukan kesalahan dan segala kemungkinan yang akan menimbulkan kesalahan. Tujuan Pengujian sistem ini adalah memastikan semua fungsional dalam sistem dapat berjalan dengan baik. Dalam pengujian sistem ini menggunakan metode White Box Testing. SUS (System Usability Scale).

Tabel 1. Pengujian Sistem dengan metode White Box Testing

\begin{tabular}{|c|c|c|c|c|c|}
\hline No & $\begin{array}{l}\text { Nama } \\
\text { File }\end{array}$ & $\begin{array}{l}\text { Nama } \\
\text { Fungsi }\end{array}$ & $\begin{array}{l}\text { Cara } \\
\text { Pengujian }\end{array}$ & $\begin{array}{l}\text { Hasil yang } \\
\text { Diharapkan }\end{array}$ & Hasil \\
\hline \multicolumn{6}{|c|}{ Warga } \\
\hline \multirow[t]{2}{*}{1} & $\begin{array}{l}\text { Warga } \\
\text {.php }\end{array}$ & $\begin{array}{l}\text { Form } \\
\text { Surat }\end{array}$ & $\begin{array}{l}\text { Pada } \\
\text { dashboard } \\
\text { pilih surat } \\
\text { yang akan } \\
\text { diajukan, } \\
\text { kemudian } \\
\text { klik tombol } \\
\text { buat surat } \\
\end{array}$ & $\begin{array}{l}\text { Menampilkan } \\
\text { form buat } \\
\text { surat }\end{array}$ & Sesuai \\
\hline & & $\begin{array}{l}\text { Aksi } \\
\text { tambah } \\
\text { permohona } \\
\text { n }\end{array}$ & $\begin{array}{l}\text { Form sudah } \\
\text { diisi, } \\
\text { kemudian } \\
\text { klik tombol } \\
\text { simpan }\end{array}$ & $\begin{array}{l}\text {-Validasi } \\
\text { form } \\
\text { •Jika berhasil, } \\
\text { maka akan } \\
\text { menampilkan } \\
\text { pesan } \\
\text { berhasil. Jika } \\
\text { gagal, maka } \\
\text { akan } \\
\text { menampilkan } \\
\text { pesan error. } \\
\text { •Redirect ke } \\
\text { halaman } \\
\text { detail } \\
\text { permohonan } \\
\text { surat }\end{array}$ & Sesuai \\
\hline 2 & Rt.php & $\begin{array}{l}\text { Aksi } \\
\text { setujui } \\
\text { permohona } \\
\text { n }\end{array}$ & $\begin{array}{l}\text { Masukkan } \\
\text { nomor surat } \\
\text { kelurahan } \\
\text { pada detail } \\
\text { permohona } \\
\text { n surat. } \\
\text { Kemudian } \\
\text { klik tombol } \\
\text { setujui }\end{array}$ & $\begin{array}{l}\cdot \text {-Validasi } \\
\text { form } \\
\text { •Jika berhasil } \\
\text { menyetujui } \\
\text { permohonan } \\
\text { surat, maka } \\
\text { akan } \\
\text { menampilkan } \\
\text { pesan } \\
\text { berhasil. Jika } \\
\text { gagal, maka } \\
\text { akan } \\
\end{array}$ & Sesuai \\
\hline
\end{tabular}




\begin{tabular}{|c|c|c|c|c|c|}
\hline No & $\begin{array}{l}\text { Nama } \\
\text { File } \\
\end{array}$ & $\begin{array}{l}\text { Nama } \\
\text { Fungsi }\end{array}$ & $\begin{array}{l}\text { Cara } \\
\text { Pengujian }\end{array}$ & $\begin{array}{l}\text { Hasil yang } \\
\text { Diharapkan }\end{array}$ & Hasil \\
\hline & & & & $\begin{array}{l}\text { menampilkan } \\
\text { pesan error. } \\
\text { •Redirect ke } \\
\text { halaman list } \\
\text { data } \\
\text { permohonan } \\
\text { selesai }\end{array}$ & \\
\hline 3 & $\begin{array}{l}\text { Admin. } \\
\text { php }\end{array}$ & $\begin{array}{l}\text { Aksi } \\
\text { setujui } \\
\text { permohona } \\
\text { n }\end{array}$ & $\begin{array}{l}\text { Masukkan } \\
\text { nomor surat } \\
\text { kelurahan } \\
\text { pada detail } \\
\text { permohona } \\
\text { n surat. } \\
\text { Kemudian } \\
\text { klik tombol } \\
\text { setujui }\end{array}$ & $\begin{array}{l}\text {-Validasi } \\
\text { form } \\
\text {-Jika berhasil } \\
\text { menyetujui } \\
\text { permohonan } \\
\text { surat, maka } \\
\text { akan } \\
\text { menampilkan } \\
\text { pesan } \\
\text { berhasil. Jika } \\
\text { gagal, maka } \\
\text { akan } \\
\text { menampilkan } \\
\text { pesan error. } \\
\text {-Redirect ke } \\
\text { halaman list } \\
\text { data } \\
\text { permohonan } \\
\text { selesai }\end{array}$ & Sesuai \\
\hline
\end{tabular}

Tabel 1 adalah memuat data-data hasil dari pengujian sistem yang dilakukan dengan menggunakan metode White Box Testing, metode pengujian ini melihat dan meneliti kedalam modul untuk dapat menganalisis kode program apakah ada yang salah atau tidak.

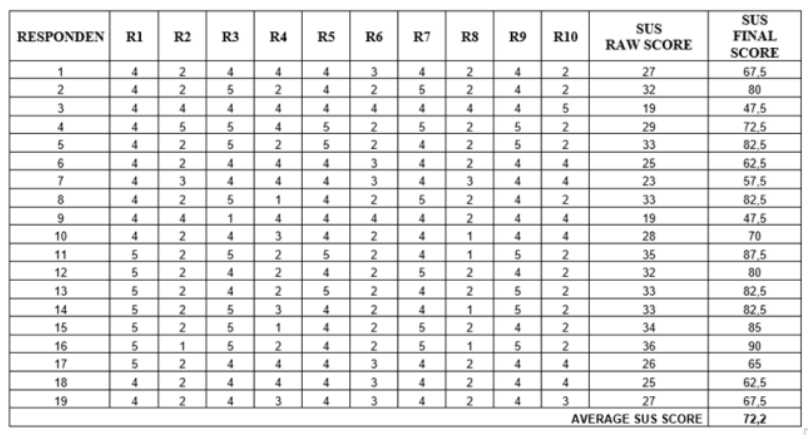

Gambar 10. Penghitungan skor SUS

Gambar 10 menerangkan hasil pengujian sistem menggunakan metode SUS (System Usability Scale) untuk menguji apakah sistem ini layak digunakan atau tidak

\section{Kesimpulan dan Saran}

Kesimpulan yang dapat diambil setelah menyelesaikan penelitian adalah pengembangan website sebagai media informasi pelayanan surat menyurat kantor Kelurahan Mendawai secara online yang dirancang menggunakan Framework PHP yaitu CodeIgniter (CI) dan Framework CSS dan JavaScript yaitu Bootstrap.

Dengan adanya website pelayanan surat menyurat ini memberikan kemudahan kepada pengguna khususnya warga Kelurahan Mendawai untuk melakukan pengajuan surat secara mandiri mulai dari pengajuan surat hingga surat tersebut telah ditandatangani oleh kepala desa dan siap digunakan untuk keperluan tertentu melalui akun yang dimiliki oleh warga tersebut.

Pihak kelurahan dapat melakukan pelayanan surat menyurat secara online dari dalam website tersebut. Selain itu, pihak kelurahan dapat melakukan pengelolaan arsip surat menyurat secara mudah dan sistematis dengan tujuan agar arsip surat tersimpan secara digital. Hal itu diperkuat dengan hasil survey System Usability Scale dengan skor 72.2 dari 19 responden yang menerangkan bahwa ketika skor yang diperoleh dari survey SUS melebihi angka 70 maka website ini dikategorikan usability.

\section{Daftar Pustaka}

[1] E. Listiyani, "Sistem Informasi Surat Pelayanan Masyarakat Desa Monggol, Kec. Saptosari, Kab. Gunungkidul, Yogyakarta," Yogyakarta Repos., p. 8, 2019.

[2] S. Y. M. Zulfikar, "Sistem Informasi Administrasi Surat Menyurat Desa Selopamioro Berbasis Web," Yogyakarta Repos., p. 8, 2019.

[3] S. Natalia, R. N. Adekayanti, and A. Karismawarjayati, "Sistem Informasi Surat Layanan Masyarakat Pada Kantor Desa Condongcatur Berbasis Web," Yogyakarta Repos., p. 7, 2019.

[4] S. Ramadhani, F. Hermawanto, and A. Mariani, "Aplikasi Pelayanan Surat Menyurat Desa Tanah Putih Berbasis Web," J. Teknol. Inf. Indones., vol. 3, no. 2, p. 54, 2019, doi: 10.30869/jtii.v3i2.265.

[5] M. Faqih, "Sistem Informasi Pelayanan Surat-menyurat Berbasis Web di Desa Palang Kecamatan Palang Kabupaten Tuban," repository.unim.ac.id., pp. 1-13, 2019. 